\author{
Review Article
}

\title{
A DRUG REVIEW ON CHEPPU NERUNJIL ENNAI - A SIDDHA HERBAL FORMULATION IN THE MANAGEMENT OF SOOLI KANAM (CHILDHOOD ASTHMA) IN CHILDREN
}

\section{Brindha. A1*, Meenakshi Sundaram.M², Meenakumari.R3}

*1PG Scholar, 2 Professor and Head of the Department, Department of Kuzhandhai Maruthuvam, ${ }^{3}$ Director, National Institute of Siddha, Chennai, Tamil Nadu, India.

Article info

Article History:

Received: 18-05-2021

Revised : 01-06-2021

Accepted: 10-06-2021

Published: 18-09-2021

KEYWORDS:

Siddha herbal

formulation,

childhood asthma,

Paediatrics.

\begin{abstract}
Siddha system is the oldest and well documented Indian traditional System of medicine. The term siddha means achieving perfection. Siddhars were saints who achieved better results in medicine. Siddhars are human beings with super intellectual capacity. Asthma is one of the most common chronic diseases of childhood. Most children develop asthma in early age. Prevalence of asthma in children increases due to growing urbanization, modernization, overcrowding and changing life styles. Asthma is a non communicable disease characterized by recurrent wheezing, breathlessness, chest tightness, and coughing. The symptoms of Soolikanam nearly correlate with childhood asthma. Numerous medicines for Soolikanam (childhood asthma) are explained in Siddha text. Cheppu Nerunjil Ennai is one of the herbal formulation indicated for Soolikanam. Cheppu nerunjil ennai was mentioned in balavagadam siddha text book. This trial drug Cheppu Nerunjil Ennai comprises of eight herbal ingredients like Indigofera linnaei, Desmodium triflorum, Euphorbia parviflora, Cassia tora, Vigna trilobata, Sesbania grandiflora, Allium cepa, Ricinus communis. The herbal ingredients of Cheppu Nerunjil Ennai possess anti asthmatic activity, anti spasmodic, anti allergic activity, anti oxidant and immunomodulatory activity. This review article reflects history, properties, chemical constituents, pharmacological activities and several medicinal uses of the drug Cheppu Nerunjil Ennai on Soolikanam. This review further focuses to improve the research on Siddha herbal medicines.
\end{abstract}

\section{INTRODUCTION}

Bronchial asthma is a heterogeneous pulmonary disorder characterized by recurrent episodes of cough, breathlessness and wheezing, which may resolve spontaneously or after the use of bronchodilator medication.[1]

The prevalence of asthma has increased over time and an additional 100 million people worldwide are expected to develop asthma by the year 2025.[2]

In the past 10 years, the proportion of Indian school children suffering from asthma has increased to more than double.

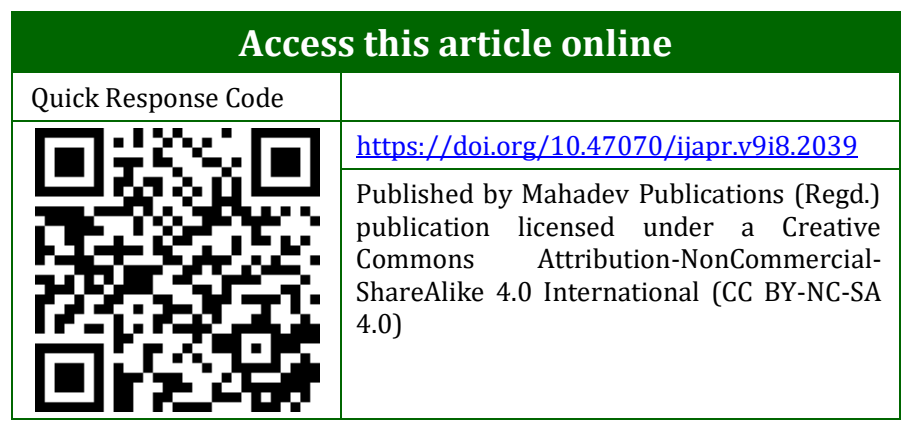

The increase in the prevalence of bronchial asthma in children may have serious implications in their adult life, as $40 \%$ children with trivial wheeze and $70 \%-90 \%$ of these with troublesome asthma continue to have symptoms in mid-adult life.[3]

Siddha medicine is an ancient healing science of South India. Siddha system of Medicine point out three cardinal energies named Vali, Azhal and Iyam. These principles are related to fundamental physiology of our body.

According to Siddha literature, which categorizes kanam, as a respiratory disease, into 24 types. Out of this 24 types, Soolikanam nearly correlates with the symptoms of childhood asthma, which is described in Siddha text Kuzhandhai Maruthuvam-Balavagadam. The drug Cheppu Nerunjil Ennai is indicated for Soolikanam in that text. ${ }^{[4]}$

Majority of ingredients in this formulation, are having anti-inflammatory, anti asthmatic, anti spasmodic, anti-oxidant, anti-microbial activities and are beneficial in respiratory diseases. 
MATERIALS AND METHODS

Table 1: Ingredients and Purification of Cheppu Nerunjil Ennai

\begin{tabular}{|c|c|c|c|c|}
\hline S.no & Name of the Plant & Used Part & Weight & Purification \\
\hline 1 & $\begin{array}{l}\text { Cheppu Nerunjil } \\
\text { Indigofera linnaei } L .\end{array}$ & Root & $\begin{array}{l}\text { Kazharchikai } \\
\text { alavu }(2.6 \mathrm{gm})\end{array}$ & $\begin{array}{l}\text { The plant was purified by cleaning the roots } \\
\text { with water for removing the dust particle. }\end{array}$ \\
\hline 2 & $\begin{array}{l}\text { Chiru Pulladi } \\
\text { Desmodium triflorum }\end{array}$ & Root & $\begin{array}{l}\text { Kazharchikai } \\
\text { alavu }(2.6 \mathrm{gm})\end{array}$ & $\begin{array}{l}\text { The plant was purified by cleaning the roots } \\
\text { with water for removing the dust particle. }\end{array}$ \\
\hline 3 & $\begin{array}{l}\text { Chiruamman Patcharisi } \\
\text { Euphorbia parviflora }\end{array}$ & Root & $\begin{array}{l}\text { Kazharchikai } \\
\text { alavu }(2.6 \mathrm{gm})\end{array}$ & $\begin{array}{l}\text { The plant was purified by cleaning the roots } \\
\text { with water for removing the dust particle. }\end{array}$ \\
\hline 4 & $\begin{array}{l}\text { Thagarai } \\
\text { Cassia tora }\end{array}$ & Root & $\begin{array}{l}\text { Kazharchikai } \\
\text { alavu }(2.6 \mathrm{gm})\end{array}$ & $\begin{array}{l}\text { The plant was purified by cleaning the roots } \\
\text { with water for removing the dust particle. }\end{array}$ \\
\hline 5 & $\begin{array}{l}\text { Naripayarankodi } \\
\text { Vigna trilobata }\end{array}$ & $\begin{array}{l}\text { Whole } \\
\text { plant }\end{array}$ & $\begin{array}{l}\text { Kazharchikai } \\
\text { alavu }(2.6 \mathrm{gm})\end{array}$ & $\begin{array}{l}\text { The plant was purified by cleaning it with } \\
\text { pure clean cloth. }\end{array}$ \\
\hline 6 & $\begin{array}{l}\text { Agathi } \\
\text { Sesbania grandiflora }\end{array}$ & Bark & $\begin{array}{l}\text { Kazharchikai } \\
\text { alavu }(2.6 \mathrm{gm})\end{array}$ & $\begin{array}{l}\text { The plant was purified by outer most layer } \\
\text { is peeled off. }\end{array}$ \\
\hline 7 & $\begin{array}{l}\text { Vengayam } \\
\text { Allium cepa }\end{array}$ & Bulb & $\begin{array}{l}\text { Kazharchikai } \\
\text { alavu }(2.6 \mathrm{gm})\end{array}$ & $\begin{array}{l}\text { Clean it with water and washed of then peel } \\
\text { of outer skin and remove the central vein of } \\
\text { the Allium cepa and dry it and it get purified. }\end{array}$ \\
\hline 8 & $\begin{array}{l}\text { Chitraamanakku Ennai } \\
\text { Ricinus communis }\end{array}$ & - & $160 \mathrm{ml}$ & - \\
\hline
\end{tabular}

\section{Method of preparation}

1. All the above ingredients were purified.

2. The roots of Cheppu nerunjil, Chiru pulladi, Chiru amman pachcharisi, Thagarai are grinded into fine powder.

3. Naripayarukodi, Agathipattai, Vengayam are grinded into paste form.

4. The above mixture is added to $160 \mathrm{ml}$ of Castor oil and stirred well.

5. Then it is kept in sunlight for 6 hours.

6. Prepared medicine is stored in clean and dry glass container.

Dosage: $5 \mathrm{ml}$, two times a day.

Duration: 7 days.

\section{Cheppu Nerunjil}

Latin name $\quad$ : Indigofera linnaei L.

Family : Fabaceae

English name : Birdsville indigo, Nine -leaved indigo

Parts used : Root

Habitat : This species grows commonly in grasslands, also in the plains, fallow field. It is widely distributed in India, indo-Malesia to Australia and West Africa.

\section{Organoleptic Characters}

Taste: Sweet

Character: Cold

Division: Sweet

Actions: Diuretic, Febrifuge

\section{Phytochemical Constituents}

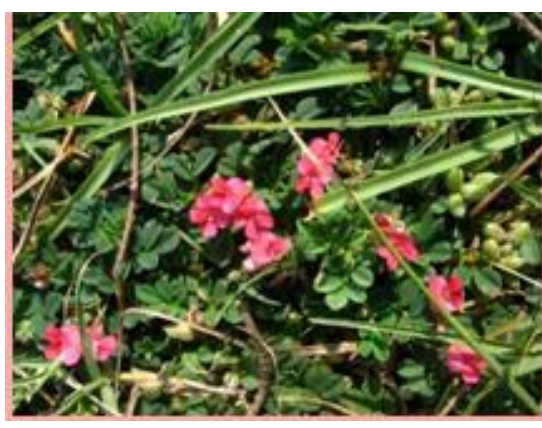

- Indigofera linnaei have tannins, saponins, flavonoids, cardiac glycoside, steroids, terpenoids, coumarins and two compounds namely, 5-[(E)-2(4-hydroxylphenyl] benzene-13-diol and gitoxin belonging to the class of tannols and steroidal glycoside. ${ }^{[5]}$

\section{Pharmacological Activity}

- Indigofera possess Anti microbial[5], Anti inflammatory[6], Analgesic activity[6], Anti-oxidant activity.[7].

\section{Therapeutic uses}

The juice of the Indigofera is used as antiscorbutic for burns. It is used by native medical practitioners to treat rheumatism, arthritis, inflammation, tumor and liver disease.

\section{Chirupulladi}

Latin name : Desmodium triflorum

Family : Fabaceae

English name: Common fumitory

Parts used : Leaves, root and whole plant 
Habitat: This species grows in moist places, grasslands and wastelands, herb found to be growing in India especially in Kerala, Maharastra, kamrup, bongaigaon.

\section{Organoleptic Characters}

Taste: Bitter,

Character: Hot

Division: Pungent

Actions: Carminative, Galactagogue, Tonic

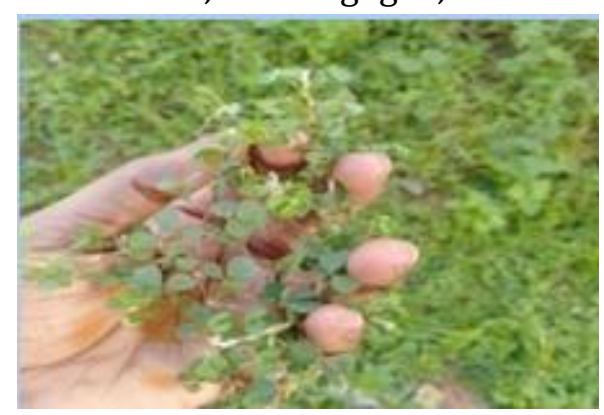

\section{Phytochemical Constituents}

Desmodium contains chemical contituients ursolic acid, vitexin, genistin, fucosterol and rare Diholosylflavane, 2-0 glucosylvitexin ${ }^{[8]}$.

Desmodium leaves contains total alkaloid, 0.01-0.015\%, bête phenethylamine (major alkaloids). It contains hypaphorine (major alkaloids) $\mathrm{N}, \mathrm{N}$ dimethyltryptophan betaine, choline.[9]

\section{Pharmacological Activity}

Desmodium possess Anti oxidant, Anti spasmodic activity, Anti inflammatory, Anti proliferative, Analgesic, Anthelminitic activity.[9]

\section{Medicinal Uses}

The leaves of Desmodium are used in diarrhea, convulsions, anti spasmodic, central nervous system stimulation, the fresh leaves of the plant are applied to wounds and abscesses that are usually difficult to heal.

The paste is sometimes applied to sores and itch. The fresh juice of the plant is often given to the children for cough asthma.

The traditional use of the plant also recommends for use in dysentery, high fever.

In Philippines a decoction is also used as mouth wash and as an expectorant.

\section{Chiru amman patcharisi}

Latin name: Euphorbia parviflora

Family: Euphorbiaceae

English name: Australian sthima weed

Parts used: Whole plant

Habitat: This species found in Indian subcontinent to indo-china.

\section{Organoleptic Characters}

Taste: Astringent, Sweet

Character: Cold

Division: Sweet

Actions: Astringent, Refrigerant, Laxative

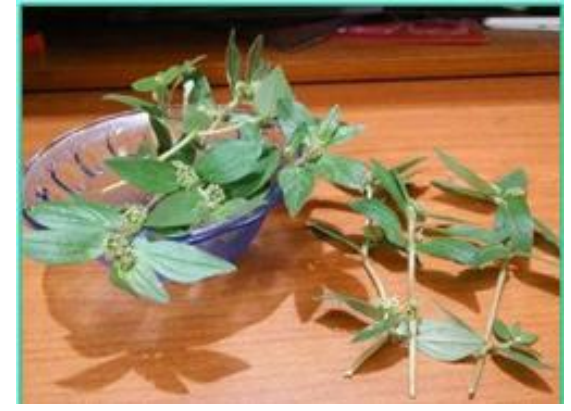

\section{Phytochemical Constituents}

- Root and stem water extracts shows positive test for tannins, saponine, alkalaoids, and flavanoids. Starch, proteins, anthroquinones, and reducing sugars. ${ }^{[10]}$

\section{Pharmacological Activity}

- Euphorbia possess Anti allergic, Anti inflammatory, Anti oxidant.[11]

\section{Medicinal Uses}

- Euphorbia is used for breathing disorders including asthma, bronchitis and chest congestion.

- It is also used for mucus in the nose and throat, throat spasm, hay fever and tumors.

\section{Thakarai}

Latin name: Cassia tora

Family: Caesalpinaceae

English name: Foetid cassia

Parts used: Flower, Seed, Leaf.

\section{Habitat}

A small shrub, common in plains from coast in low lying places, river banks, fallow fields, wastelands. Found up to $1400 \mathrm{~m}$.Distribution of this plant is India to Polynesia.

\section{Organoleptic Character}

Taste: Bitter, Salt

Character: Hot

Division: Pungent

Actions: Febrifuge, Germicide

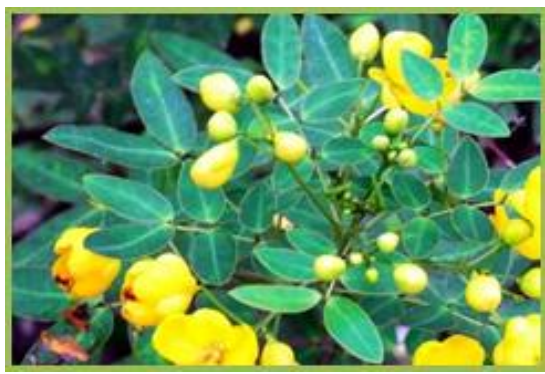

\section{Phytochemical Constituents}

Cassia tora seed possess alkaloids, flavonoids, terpinoides, saponin. tannin, amino acids, protein and glycosidase. [12]

The cassia tora roots contain presence of 1,3,5trihydroxy-6-7-dimethoxy-2-methyl anthroquinone and $\beta$-sitosterol. 
The leaves a rich in emodin, tricontan-1-ol, stigmasterol, $\beta$-sitosteral- $\beta$-d-glucoside, freindlen, palmitic, stearic, succinic and d-tartaric acids, uridine, quercitrin and iso-quercitrin

The flowers are reported to contain kaempferol and leucopelargonidin.[13]

\section{Pharmacological Activity}

Cassia possess Anti asthmatic activity, Anti inflammatory, Antinociceptive activity, Anti oxidant, Anti microbial activity, Anti bacterial activity, Anti helminthic activity, Hepatoprotective and immunostimulatory.[14]

\section{Medicinal Uses}

Seeds have anti parasitic properties. The paste of seeds is applied topically on ringworms and scabies.

The decoction of whole plant is given as a vermifuge, the root of the plant are used as a bitter tonic, stomachic and leaves as an antiperiodic aperients and anthelmintic.

Leaf decoction is used for fever, cough, blood dysentery, and diarrhea.

The dried root of cassia tora is good purifier of blood and tonic.

\section{Naripayarankodi}

Latin name: Vigna trilobata

Family: Fabaceae

English name: Wild gram

Parts used: Leaf, Seed

Habitat: It is distributed in rocky areas in dry and moist deciduous forests and plain areas. Cultivating mainly in India: Kerala, Assam, Bihar, Gujarat, Maharastra.

\section{Organoleptic Characters}

Taste: Sweet

Character: Cold

Division: Sweet

Actions: Refrigerant, Expectorant

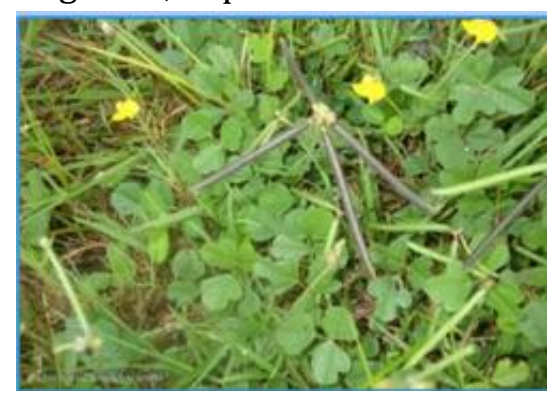

\section{Phytochemical Constituents}

Vigna trilobata possess Amino acids, valine, leucine, tyrosine, Phenylalanine, Lysine Isoleucine, flavinoids, glycosides, isovitexin, kaempferol, kievitone, quercitin, saponins, sterols, vitexin, tannins, Vitamin K, C[15]

\section{Pharmacological Activity}

Vigna posses Anti oedema, Anti-inflammatory, Hepato protective, Anti oxidant [16].

\section{Medicinal Uses}

The roots use for Fever, cough, worm infestation, gout, wound inflammation, useful in diarrhea, irritable bowel syndrome, improves vision, good for eye disorders.

\section{Agathi}

\section{Latin name: Sesbania grandiflora \\ Family: Fabaceae \\ English name: Sesban, Sawamp, and pea \\ Parts used: Leaf, flower, seed, root}

Habitat: This species grows commonly in wet places, and along marshes. Plant commonly distributed in India. In India distribution of this plant is widely available in Assam, Maharastra, Tamil Nadu, Uttar Pradesh.

\section{Organoleptic Characters}

Taste: Bitter

Character: Cold

Division: Pungent

Actions: Astringent, Tonic

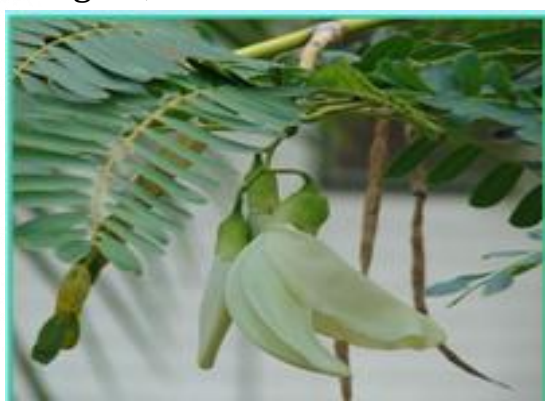

\section{Phytochemical}

Leucocyanidin and cyanidine present in seeds, Oleanolic acid and its methyl ester and kaemferol-3rutinoside which are present in flower. The bark contains tannins and gum. Saponin and sesbanimide isolated from seeds.[17] Isoflavanoids, isovestitol, medicarpin, sativan, betulinic acid, aspartic acid, alanine.[18]

\section{Pharmacological Activity}

Sesbania possess Anti oxidant, Anti bacterial, Anti inflammatory, Hepato protective[19]. Leaves have antimicrobial activity. Anti diarrheal..[20]

\section{Medicinal Uses}

Crushed leaves are applied as a poultice to sprains and bruises of all kinds, swellings, rheumatism, itching.

The bitter bark is considered as an astringent, febrifuge, tonic and an antipyretic, a remedy for gastric troubles, colic with diarrhea and dysentery. The bark decoction is taken orally to treat fever, diarrhea and dysentery and diabetes. 


\section{Vengayam}

Latin name: Allium cepa

Family: Liliaceae

English name: Onion

Parts used: Bulb

Habitat: Allium cepa originates from Central Asia. It is cultivated in all over India. Onions are growing most in any soil, chiefly in the temperature zones.

\section{Organoleptic Characters}

Taste: Bitter

Character: Hot

Division: Pungent

Actions: Stimulant, Diuretic, Expectorant, Emmenagogue, Demulcent, Aphrodisiac

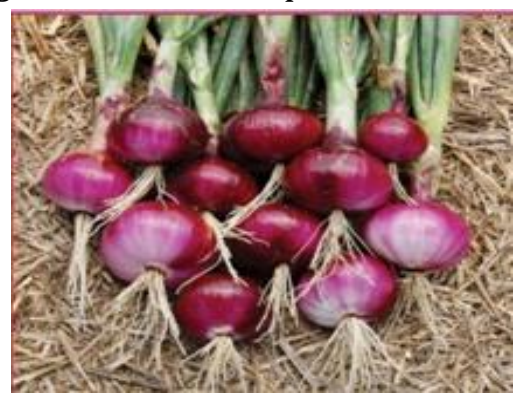

\section{Phytochemical Constituents}

Allium cepa possess high levels of phenolic compounds, flavonoids are the major phenolic in onion. Onion bulbs contain inulin, kestose, nystose and fructofuranosylnytose. Flavonols are rich in onions, present as glycosides, named quercetin and kaempferol. Anthocyanins $(250 \mathrm{mg} / \mathrm{kg})$ mostly present in red onions.

Onions are also hold vitamin $\mathrm{C}, \mathrm{B}_{6}$, potassium and chromium.

Sulfur compounds are responsible for odor and flavor; these are main volatile compounds in onion. Other compounds like, aldehyde and ketones are present in minor amount, that is (17-21\%) and (3-7\%) respectively. [21]

\section{Pharmacological Activity}

Allium possess Anti spasmodic, Anti asthmatic activity, [22] Anti bacterial activity, Anti viral activity, Anti oxidant, Anti inflammatory activity, Expectorant, Bronchodilator.[23]

\section{Medicinal Uses}

Onion as medicine help in treating sore throat, asthma, bronchitis, cough, high cholesterol, diabetes, joint disorders, digestive ailments, loss of appetite, gall bladder diseases, angina pectoris, high blood pressure, atherosclerosis.

\section{Aamanakku ennai}

Latin name: Ricinus communis

Family: Euphorbiaceae

English name: Castor oil
Parts used: Seeds

\section{Habitat}

A weed of river beds, waterways, roadsides, railways and other waste areas in tropical, sub-tropical and temperature environments.

\section{Organoleptic Characters}

Taste: Bitter

Character: Hot

Division: Pungent

Action: Laxative, Emollient

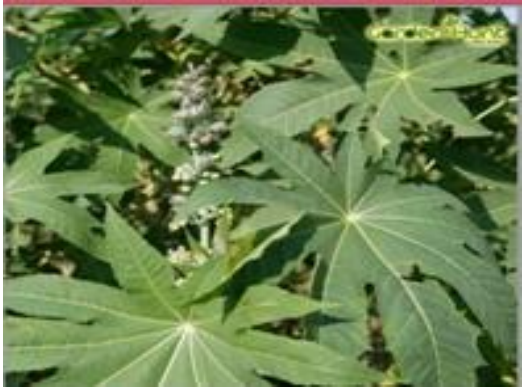

\section{Phytochemical Constituents}

Seeds and fruits possess $45 \%$ of fixed oil. Seed oil contain $12 \%$ of palmitic acid, $0.7 \%$ of stearic acid, $0.3 \%$ of arachidic acid, $0.2 \%$ of hexadecenoic acid, $3.2 \%$ oleic acid, 3.4\% linoleic acid and $89.4 \%$ of ricinoleic acid.[24]

Steroids, saponins, alkaloids, flavanoids and glycosides are present in it. $0.55 \%$ of ricinine and $0.016 \%$ of $\mathrm{N}$-demethylrecinine are 2 main alkaloids present in leaves. ${ }^{[25]}$

\section{Pharmacological Activity}

Ricinus communis possess anti histaminic activity, anti spasmodic, anti asthmatic activity, anti microbial, anti oxidant, anti inflammatory activity, hepato protective [26]

Plant extract of R.Communis contain antimicrobial activity against various micro-organisms such as, Staphylococcus aureus, Bacillus subtilis, proteus vulgaris, candida albicans and aspergillus niger.

Due to the presence of flavanoids, extract of this plant has anti-inflammatory activity.

\section{Medicinal Uses}

Ricinus communis have been widely used in traditional medicine such as abdominal disorders, arthritis, backache, muscle aches, constipation, insomnia, menstrual cramps, promotes wound healing.

\section{CONCLUSION}

In the present review reveals, that the medicinal plants in this drug 'Cheppu Nerunijl Ennai' are very effective and safer for medicinal uses. The ingredients of Cheppu Nerunjil Ennai having antiinflammatory, anti-asthmatic, bronchodilator, antimicrobial and antioxidant activities. So it will be correcting respiratory disease. The phytochemicals which are present in these plants are mostly steroids 
and alkaloids which are responsible for the actions. So from the current article concludes that these medicinal plants are having high medicinal values. The Cheppu Nerunjil Ennai contain a higher proportion of phytochemicals and pharmacological activities which would be responsible for its significant effect on Soolikanam (Childhood Asthma). So Cheppu Nerunjil Ennai may be considered as a extensive medicine for the management of childhood asthma.

\section{REFERENCES}

1. Agarwal R, Dhooria S, Aggarwal AN, Maturu VN, Sehgal IS, Muthu V, et al. Guidelines for diagnosis and management of bronchial asthma: Joint ICS/ NCCP (1) recommendations. Lung India 2015; 32:S3-42.

2. D Behera, Inderpaul singh sehgal. Bronchial asthma- issues for the developing world. The Indian journal of Medical Research 141(4):380-2.

3. Vandana kumari, Tushar Bharat Jagzape. Bronchial asthma: Prevalence and risk factors among children in urban population from Raipur, Chhattisgarh.2019, vol 33, issue 1, pg no 45-50.

4. Murugesa mudhiliyar and and Dr.Pon. Gurusironamani, Kuzhandhai Maruthuvam, Balavagadam, published by Indian and Homeopathy medicine,2016, Pg no 212,213.

5. M.S.Sandhyavali, P.Sivakamisundari, $\odot$ Pannu Sharmaand V.Murugan. Phytochemical studies on the aerial parts of Indigofera Linnaei. Pharmacophore 2014, Vol 5(1), 94-97.

6. Raju senthil kumar, balasubraminan rajkapoor beneficial effects of methanolic extract of Indigofera linnaei ali, braz,.Pharm.sci.vol.52 no 1sao Paulo jan./mar.2016

7. R.Senthil kumar, B.Rajkapoor, P.Perumal. Antioxidant potential of Indigofera linnaei-an in vitro study. Pharmacology online1:170-720(2011)

8. Venkateswara Rao Gavalapu, Prabhanjan kolli, Sanjeev kumar korra, Manoj kumar,kavuri, Chandrasekhar avagagadda, Venkataramya Singam, Yernikumari vanumu and harish kudirella. Preliminary Phytochemical screening and anthelminitic activity of Desmodium triflorum(L) Dc Leaf and Root Extracts. International Journal of Pharma Sciences. Vol 3, No. 1(2013) 156-158.

9. Anu K, Thankachan, Meena Chandran, K. Krishnakumar. Pharmacological activity of Desmodium triflorum-A review. Asian journal of Phytochemedicine and clinical research. 5(10), 2017,33-41.

10. B K Avchar. Allelopathic evaluation of euphorbia parviflora L. Aqueous leachates on wheat. Scholar academic journal of biosciences. Sch Acad J Biosci, April, 2020; 8(4): 77-80.
11. Ali esmail, Al-snafi. pharmacology and therapeutic potential of euphorbia pilulifera, IOSR journal of pharmacy 7(3),7-20,2017.

12. V.B. Suradkar, B.B. Wankhade, P.G.Dabbe. Phytochemical analysis of some contents of Cassia tora and Xanthium strumarium plants seeds. International journal of advanced research in science, engineering and technology.vol 4, issued 4, 2017.

13. Smita Jain, U K Patil. Phytochemical and pharmacological profile of cassia tora Linn-An overview. Indian Journal of natural products and resources vol 1(4) 2010. 430-437.

14. Manjusha Choudhary, Yuvaraj Gulia, Nitesh. Cassia tora: its chemistry, medicinal uses and pharmacology. Pharmacologyonline3: 78-96(2011)

15. Navpreet Kau, Rashmi, Y.C.Tripathi and Lokesh Uadhyay. Phytochemical and antidiabetic evaluation of Phaseolus trilobus roots. Journal of research 2012, 5 (11), 5202-5205.

16. Fursule RA, Patil SD, Hepatoprotective and antioxidant activity of phaselous trilobus, Ait on bile duct ligation induced liver fibrosis in rats. Journal of Ethnopharmacology 2010; 129(3):416419.

17. Vijay D.Wagh, Kalpana V.Wagh, Yogyata N.Tandalea and shubhangi A. Salvi phytochemical, pharmacological and phytocpharmaceutics aspects of sesbania grandiflora: A review. Journal of pharmacy Research 2009,2(5),889-892.

18. Noviany hasan, Hasnah osman, suriyati mohamad,the chemical components of sesbania grandiflora root and their antituberculosis activity, pharmaceuticals 2012,5(8), 882-889: https://doi. org/ 10.3390/ph5080882, pub:23 aug 2012.

19. Nafisa binte arfan, Azima sultana julle, Ak moliuddin, medicinal properties of the sesbania grandiflora, Ibnosina J Med BS2016; 8960;271-277

20. Thrombolytic, Membrane stabilizing, Antidiarrhoeal, and Antimicrobial properties of Bioactive compounds isolated from leaves of Sesbania grandiflora naturally growing in Bangladesh. Iranian journal of pharmaceutical science 2016:12(3):31-46.

21. Loredana Liguori, Rosa Califano, Donatella Albanese, Francesco Raimo, Alessio Crescitelli, and Marisa Di Matteo, Chemical Composition and Antioxidant Properties of Five White Onion (Allium cepa L.) Landraces, Journal of Food Quality Volume 2017, Article ID 6873651, 9 pages https://doi.org $/ 10.1155 / 2017 / 6873651$

22. Walter dorch, Michael ettl, guido hein, antiasthmatic effects of onions inhibition pf platelet-activating factor-induced bronchial asthma 
Brindha. A et al. A Drug Review on Cheppu Nerunjil Ennai-the Management of Sooli Kanam (Childhood Asthma) in Children

by oils, int. archs allergy applimmun,82:535-536 (1987).

23. Sonia Jose and K. Krishnakumar, A review on phytochemical and pharmacological studies on Allium cepa, Asian Journal of Pharmaceutical Analysis and Medicinal Chemistry. 5(1), 2017, 32 36.

24. Manoj Kumar, A Review on Phytochemical Constituents and Pharmacological Activities of Ricinus communis L. Plant, International Journal of Pharmacognosy and Phytochemical Research 2017; 9(4); 466-472.
25. Jennifer suurbaar, Richard Mosobil \&AddaiMensah Donkor. Antibacterial and antifungal activities and Phytochemical profile of leaf extract from different extractants of Ricinus Communis against selected pathogens. BMC research notes.10, article no 660(2017).

26. Jitendra jena, huashish kumar gupta, Ricinus communis linn: a phytopharmacological review, international journal of pharmacy and pharmaceutical sciences, vol 4, issue4, pp.21-29, 2012.

\section{Cite this article as:}

Brindha. A, Meenakshi Sundaram.M, Meenakumari.R. A Drug Review on Cheppu Nerunjil Ennai- A Siddha Herbal Formulation in the Management of Sooli Kanam (Childhood Asthma) in Children. International Journal of Ayurveda and Pharma Research. 2021;9(8):75-81.

https://doi.org/10.47070/ijapr.v9i8.2039

Source of support: Nil, Conflict of interest: None Declared

\section{*Address for correspondence}

Dr Brindha. A

PG Scholar

Department of Kuzhandhai

Maruthuvam,

National Institute of Siddha,

Chennai-47

Email:

abrindha149@gmail.com

Disclaimer: IJAPR is solely owned by Mahadev Publications - dedicated to publish quality research, while every effort has been taken to verify the accuracy of the content published in our Journal. IJAPR cannot accept any responsibility or liability for the articles content which are published. The views expressed in articles by our contributing authors are not necessarily those of IJAPR editor or editorial board members. 